\title{
Latent tuberculosis infection, tuberculin skin test and vitamin D status in contacts of tuberculosis patients: a cross-sectional and case-control study
}

\author{
Alberto Arnedo-Pena ${ }^{1,4^{*}}$, José Vicente Juan-Cerdán², Angeles Romeu-Garcia', Daniel Garcia-Ferrer², \\ Rita Holguín-Gómez ${ }^{3}$, Jesús Iborra-Millet ${ }^{2}$, Concepción Herrero-Carot ${ }^{1}$, María Jesús Sanchis Piñana², \\ Juan Bellido-Blasco ${ }^{1,4}$, José Antonio Ferrero-Vega², Lourdes Safont Adsuara', Esther Silvestre Silvestre', \\ Noemi Meseguer Ferrer ${ }^{1}$ and Vicenta Rodrigo Bartual ${ }^{5}$
}

\begin{abstract}
Background: Deficient serum vitamin D levels have been associated with incidence of tuberculosis (TB), and latent tuberculosis infection (LTBI). However, to our knowledge, no studies on vitamin D status and tuberculin skin test (TST) conversion have been published to date. The aim of this study was to estimate the associations of serum 25-hydroxyvitamin $\mathrm{D}_{3}(25[\mathrm{OH}] \mathrm{D})$ status with LTBI prevalence and TST conversion in contacts of active TB in Castellon (Spain).

Methods: The study was designed in two phases: cross-sectional and case-control. From November 2009 to October 2010, contacts of 42 TB patients (36 pulmonary, and 6 extra-pulmonary) were studied in order to screen for TB. LTBI and TST conversion cases were defined following TST, clinical, analytic and radiographic examinations. Serum 25(OH)D levels were measured by electrochemiluminescence immunoassay (ECLIA) on a COBAS ${ }^{\circledR} 410$ $\mathrm{ROCHE}^{\circledR}$ analyzer. Logistic regression models were used in the statistical analysis.

Results: The study comprised 202 people with a participation rate of $60.1 \%$. Only $20.3 \%$ of the participants had a sufficient serum $25(\mathrm{OH}) \mathrm{D}(\geq 30 \mathrm{ng} / \mathrm{ml}$ ) level. In the cross-sectional phase, 50 participants had LTBI and no association between LTBI status and serum 25(OH)D was found. After 2 months, 11 out of 93 negative LTBI participants, without primary prophylaxis, presented TST conversion with initial serum 25(OH)D levels: a:19.4\% (7/36): < 20 ng/ml, b:12.5\% (4/ 32): $20-29 \mathrm{ng} / \mathrm{ml}$, and c:0\%(0/25) $\geq 30 \mathrm{ng} / \mathrm{ml}$. A sufficient serum 25(OH)D level was a protector against TST conversion a: Odds Ratio $(\mathrm{OR})=1.00 ; \mathrm{b}: \mathrm{OR}=0.49$ (95\% confidence interval $(\mathrm{Cl})$ 0.07-2.66); and c: $\mathrm{OR}=0.10$ (95\% Cl 0.00-0.76), trends $p=0.019$, adjusted for high exposure and sputum acid-fast bacilli positive index cases. The mean of serum level $25(\mathrm{OH})$ D in TST conversion cases was lower than controls, $17.5 \pm 5.6 \mathrm{ng} / \mathrm{ml}$ versus $25.9 \pm 13.7 \mathrm{ng} / \mathrm{ml}(p=0.041)$.
\end{abstract}

Conclusions: The results suggest that sufficient serum 25(OH)D levels protect against TST conversion.

Keywords: Tuberculosis, Vitamin D, Latent tuberculosis infection, Tuberculin skin test conversion, Case-control study

\section{Background}

The hypothesis of vitamin D (VitD) deficiency as a risk factor for tuberculosis (TB) was postulated by Peter Davies, based on epidemiological studies of immigrants from India who developed active $\mathrm{TB}$ in the United

\footnotetext{
* Correspondence: arnedo_alb@gva.es

${ }^{1}$ Epidemiology Division. Public Health Center Castellón, Spain

Full list of author information is available at the end of the article
}

Kingdom [1]. Low levels of VitD in blood are associated with TB [2-4], and hypovitaminosis D is frequent in patients with TB [5] and children with latent tuberculosis infection (LTBI) [6]. In addition, epidemiological studies of geographic or seasonal variations of TB incidence [7-11] and differences in the efficacy of the Micobacterium bovis bacillus Calmette-Guérin (BCG) vaccine according to latitude, suggest that a reduction of VitD levels could increase TB risk [12,13]. Furthermore,

\section{C) Biomed Central}


in vitro studies [14] and a meta-analysis of studies of vitamin $\mathrm{D}$ receptor genetic polymorphisms support the VitD hypothesis [15]. However, there are controversies about the actions of VitD on the infection: Bruce and coauthors indicated [16] that: "The evidence does not support a positive or negative role for VitD in host resistance to infection", an alternative VitD action has been proposed [17], other factors apart from VitD could be important in relation to the seasonality of TB incidence [18-20], and the VitD hypothesis continues to be questioned [21].

It has been indicated that the hypothesis of VitD deficiency as a risk factor of TB could be tested by in vitro studies of immune responses or by case-control studies [22]. In studies where the cases are patients with active TB, it is difficult to differentiate whether low VitD levels are a cause or a consequence of the disease [23]. The study of LTBI in relation to VitD levels using a cross-sectional design presents a similar problem with positive LTBI cases $[24,25]$. The study of LTBI in contacts of TB patients and potential tuberculin skin test (TST) conversions could be considered as an alternative design. To our knowledge, no studies of VitD status and TST conversion have been published to date. The objective of our study was therefore to estimate associations of VitD status with LTBI prevalence and TST conversion in contacts of TB patients.

\section{Methods}

The study was designed in two phases: the first phase was cross-sectional and the second, a case-control study. The period of study was from November 2009 to October 2010. The study involved two health departments in the province of Castellón (Spain), located on the east cost of the Iberia Peninsula at latitude $39^{\circ} \mathrm{N}$. The two departments have population of 470,000 . The mean annual hours of sunshine was 2689 for the period 1971-2000 according to data from the Ministry for the Environment http://www.aemet.es/es/elclima. VitD from sun exposure is considered to be scarce during the autumn and winter. The median annual rates of pulmonary and extra-pulmonary TB for years 2006-2010, were 13.4 per 100,000 inhabitants and 1.9 per 100,000 inhabitants, respectively, and the proportion of foreign-born cases was $44.6 \%$. Although these incidences could be considered low, they are higher than most other European countries. In the study period, 53 cases of pulmonary TB and 9 cases of extra-pulmonary TB were reported to the Castellón Public Health Center. When a case of TB is reported, an epidemiological study of the case is carried out by the Epidemiology Division, and contacts of TB patients are invited to a medical examination that includes clinical, analytic and radiographic tests in order to control and prevent the disease.

The study had two phases. In phase I, contacts of TB patients were studied in the Epidemiology Division of the
Public Health Center and the Preventive Medicine Service of Hospital La Plana (Vila-real). After an extensive interview, a TST with 2 TU (tuberculin units), equivalent to $5 \mathrm{IU}$ (international units) of PPD (purified protein derivative RT-23) from the Serologic Institute of Copenhagen, was performed following the Mantoux technique. The test was read 72 hours later. A LTBI case was defined following a positive TST test result and negative clinical, analytic and radiographic examinations. The TST evaluation was considered positive in non BCG-vaccinated participants with an induration of $\geq 5 \mathrm{~mm}$, or BCG-vaccinated participants with an induration of $\geq 15 \mathrm{~mm}$ or the presentation of vesicles [26]. After 7 days, a booster TST was conducted on participants older than 54 years or BCG-vaccinated with a negative first TST. Participants with a history of TB or with history of treatment for LTBI were considered positive LTBI. Participants with a negative TST were considered as controls in this phase. The extensive interviews with participants provided information on the nature of contacts (household members, family members, friends, work or study colleagues), and an average number of hours per day spent in close contact with the TB patient (high exposure: 6 or more hours/day, medium exposure: 1-5 hours/day, and low exposure: $<1 \mathrm{~h} /$ day). A selfreport questionnaire gathered information on the participants' clinical history, demographic variables, weight and height, habits, use of VitD supplements, and other variables.

The serum level of 25 hydroxyvitamin $\mathrm{D}_{3}(25[\mathrm{OH}] \mathrm{D})$ was measured by electrochemiluminescence immunoassay (ECLIA) on a COBAS ${ }^{\circledR} 410$ ROCHE $^{\circledR}$ automate analyzer $[27,28]$ in the Biochemical Laboratory of the Hospital General of Castellon. Serum 25(OH)D levels from 0-19 $\mathrm{ng} / \mathrm{ml}$ range were considered as deficient, 20-29 $\mathrm{ng} /$ $\mathrm{ml}$ range as insufficient, and $\geq 30 \mathrm{ng} / \mathrm{ml}$ range as sufficient $[29,30]$. The analysis was performed on the day the TST was read, and laboratory staff were unaware of the TST results.

In phase II (case-control study), two months later, a new TST was performed on the people who tested LTBI negative in the first study. TST conversion in non BCGvaccinated participants was considered as the change from negative to positive TST with an increase of $\geq 5$ $\mathrm{mm}$ on the induration, and in BCG-vaccinated participants an increase of $\geq 10 \mathrm{~mm}$ on the induration from the initial TST, or the presence of vesicles, (26,31-32). New clinical, analytic and radiographic examinations were carried out to exclude active TB. Cases were the participants with positive TST conversion, and controls who presented negative TST results. Three participants received primary prophylaxis and were excluded from the casecontrol study, and all controls were contacts of pulmonary TB patients. 
Considering the high percentage of BCG-vaccinated participants and the low specificity of TST, an alternative analysis was carried out. Participants with high exposure, sputum AFB-positive index cases and a TST with $\geq 5 \mathrm{~mm}$ of induration were defined as LTBI positive. Participants without this contact and a TST with $\geq 10 \mathrm{~mm}$ of induration were defined as LTBI positive [33] and BCG status was not considered. The same TST conversion criterion was used.

\section{Statistical methods}

Qualitative variables were compared with Chi2 and Fisher tests; quantitative variables were compared using the Kruskal-Wallis test. Odds ratios (OR) with 95\% confidence intervals $(\mathrm{CI})$ were calculated by logistic regression. In the models, prevalent LTBI in phase I, and TST conversion in phase II were taken as dependent variables. Independent variables were demographic conditions and potential risk or protective factors. The independent variables associated with a $\mathrm{p}<0.20$ with dependent variables were included in the logistic regression models, to finally obtain those associated with a $\mathrm{p}<0.05$. The statistical programs used were STATA version 9 and LogXact $[34,35]$.

The study was approved by the Hospital General of Castellón Ethics Committee, and signed informed consent was obtained from all the participants or their parents. Children younger than 6 years of age were not included in the study.

\section{Results}

From October 2009 to November 2010, 62 TB cases were reported and $42 \mathrm{~TB}$ cases were included in the study, 28 cases of pulmonary TB with sputum acid-fast bacilli (AFB) positive smear and culture positive Mycobacterium tuberculosis, 8 cases of pulmonary TB with culture positive M. tuberculosis and sputum AFB-negative smear, 3 cases of TB pleurisy with culture negative $M$. tuberculosis, and 3 cases of lymph node TB (1 culture positive and 2 culture negative $M$. tuberculosis). The study population comprised 202 contacts of TB patients with a participation rate of $60.1 \%(202 / 336)$. The non-participants presented significant differences in the study variables, and were younger than participants, with a lower foreign-born proportion and less exposure and sputum AFB-positive index cases. Contacts of active TB patients were household members, family members, friends, and work or study colleagues. No active TB was found among the contacts.

Table 1 presents the description of the study population broken down into Spanish and foreign-born participants. The foreign-born participants came from Eastern Europe, the Maghreb, and Latin America. No differences were observed in relation to age, gender, or serum 25(OH)D levels. However, the foreign-born participants presented more sputum AFB-positive index cases, higher exposure, and a higher proportion of BCG vaccination than Spanish participants. Only $20.3 \%$ of the participants had a sufficient serum 25(OH)D level. All participants with serum 25 $(\mathrm{OH}) \mathrm{D}$ levels below $30 \mathrm{ng} / \mathrm{ml}$ were referred to a primary care physician with recommendations to take VitD supplements.

The results of the cross-sectional study are shown in Table 2. The prevalence of LTBI was $24.8 \%$ (50/202), and associated factors were male gender, exposure, and high exposure and sputum AFB-positive index cases. Preventive chemotherapy was indicated for 35 out of 50 participants with LTBI, after ruling out the disease. Three out of 14 participants with negative TST results, considering high exposure and sputum AFB-positive index cases, received primary prophylaxis with isoniazid for a two months period, after which one person presented TST conversion. These indications were independent of VitD status. Serum $25(\mathrm{OH}) \mathrm{D}$ levels were not associated with the prevalence of LTBI. However, sufficient 25(OH)D levels was a protector, although not significant $(\mathrm{OR}=0.82$ 95\% CI 0.36-1.87). The three participants, who received primary prophylaxis, had low 25(OH)D levels, 13.16, 22.4, and $22.72 \mathrm{ng} / \mathrm{ml}$, respectively. In the multivariate analysis, LTBI prevalence was not associated with serum $25(\mathrm{OH}) \mathrm{D}$ levels.

In the second phase, the rate of participation was $69.6 \%$ (96/138) of the LTBI negative participants in phase I. Significant differences in the study variables were not found between participants and non-participants, except for the high proportion of foreign-born (59.5\% versus $33.3 \% \mathrm{p}=$ $0.004)$ non-participants. Twelve out of 96 participants (12.5\%) presented TST conversion, and their characteristics are shown in Table 3. Seven patients were BCG-vaccinated, and all but one had sputum AFB-positive index case. All participants that presented TST conversion received preventive chemotherapy with isoniazid. These three participants with primary prophylaxis of TB were excluded of case-control study.

In the case-control study, 11 cases with positive TST conversion and 82 controls with negative TST results participated. The results of the case-control study are shown in Table 4. High exposure to TB patient was associated with TST conversion ( $\mathrm{p}=0.014)$, and high exposure and sputum AFB-positive index cases presented strong association with TST conversion. The use of VitD supplements was not associated with TST conversion. All eleven TST conversion cases and 57 controls (69.5\%) had low $25(\mathrm{OH}) \mathrm{D}$ levels, with means of $25(\mathrm{OH}) \mathrm{D}$ concentrations of $17.5 \pm 5.6 \mathrm{ng} / \mathrm{ml}$ and $25.9 \pm 13.7 \mathrm{ng} / \mathrm{ml}$, respectively $(\mathrm{p}=0.041)$. Seasonal variations in serum 25 $(\mathrm{OH}) \mathrm{D}$ levels were observed. A significant tendency $(\mathrm{p}=$ 0.034 ) was observed between TST conversion and 25 $(\mathrm{OH}) \mathrm{D}$ levels: $0-19 \mathrm{ng} / \mathrm{ml}, 20-29 \mathrm{ng} / \mathrm{ml}$, and $\geq 30 \mathrm{ng} / \mathrm{ml}$, with OR of 1.00, 0.60 (95\% CI 0.12-2.66), and 0.13 (95\% CI 0.00-0.91), respectively. When logistic regression 
Table 1 Characteristics of the study population: Spanish and foreign-born participants

\begin{tabular}{|c|c|c|}
\hline Variables & Spanish $\mathrm{n}=119(\%)$ & Foreign-born $\mathrm{n}=83(\%)$ \\
\hline Age (Mean \pm SD) & $39.9 \pm 14.3$ & $32.9 \pm 19.9$ \\
\hline Male (\%) & $66(55.5)$ & $46(55.4)$ \\
\hline $25(\mathrm{OH})$ Vitamin $\mathrm{D}_{3} \mathrm{ng} / \mathrm{ml}($ Mean $\pm \mathrm{SD})$ & $23.8 \pm 13.8$ & $23.68 \pm 12.9$ \\
\hline Vitamin $25(\mathrm{OH}) \mathrm{D}_{3} \mathrm{ng} / \mathrm{ml}$ (Mean $\pm \mathrm{SD}$ ) Oct-March period & $19.5 \pm 7.8$ & $16.58 \pm 7.41$ \\
\hline Vitamin $25(\mathrm{OH}) \mathrm{D}_{3} \mathrm{ng} / \mathrm{ml}$ (Mean $\pm \mathrm{SD}$ ) Apr-Sept period & $25.7 \pm 15.5$ & $28.86 \pm 13.6$ \\
\hline \multicolumn{3}{|l|}{$25(\mathrm{OH})$ Vitamin $\mathrm{D}_{3}$ levels } \\
\hline 0-19 ng/ml & $55(46.2)$ & $34(41.0)$ \\
\hline $20-29 \mathrm{ng} / \mathrm{ml}$ & $38(31.9)$ & $34(41.0)$ \\
\hline$\geq 30 \mathrm{ng} / \mathrm{ml}$ & $26(21.8)$ & $15(18.0)$ \\
\hline \multicolumn{3}{|l|}{ Exposure to TB patient } \\
\hline High & $35(29.4)$ & 29(34.9) \\
\hline Medium & $51(42.9)$ & $44(53.0)$ \\
\hline Low & $33(27.7)$ & $10(12.1)$ \\
\hline High exposure and sputum AFB-positive index cases & $19(15.9)$ & $21(25.3)$ \\
\hline BCG vaccination & $36(30.3)$ & $62(74.7)$ \\
\hline \multicolumn{3}{|l|}{ Tuberculosis types } \\
\hline Pulmonary TB sputum positive AFB smear & $81(68.1)$ & $74(89.9)$ \\
\hline Pulmonary TB sputum positive culture M. tuberculosis & $28(23.5)$ & $3(3.6)$ \\
\hline Pleurisy & $7(5.9)$ & $2(2.4)$ \\
\hline Lymph node & $3(2.5)$ & $4(4.8)$ \\
\hline \multicolumn{3}{|l|}{ Foreign-born population } \\
\hline Eastern Europe & & $41(49.4)$ \\
\hline Maghreb & & $13(15.7)$ \\
\hline Latin America & & $29(34.9)$ \\
\hline
\end{tabular}

$\mathrm{SD}=$ Standard deviation. $\mathrm{BCG}=$ bacilli Calmette-Guerin. $\mathrm{AFB}=$ Acid Fast Bacilli. $\mathrm{TB}=$ Tuberculosis

models were performed, sufficient 25(OH)D level presented a significant inverse association with TST conversion $(\mathrm{OR}=0.1095 \% \mathrm{CI} 0.00-0.76)$, adjusted for high exposure and sputum AFB-positive index cases with a significant tendency $(\mathrm{p}=0.019)$ (see Table 5).

Results of the alternative analysis revealed 10 participants out of 86 (11.6\%) with TST conversion. The distribution of participants' serum $25(\mathrm{OH}) \mathrm{D}$ levels and TST conversion were $18.2 \%(6 / 33):<20 \mathrm{ng} / \mathrm{ml} ; 14.3 \%(4 / 28)$ $20-29 \mathrm{ng} / \mathrm{ml}$; and $0.0 \%(0 / 25) \geq 30 \mathrm{ng} / \mathrm{ml}$, respectively. A significant tendency $(\mathrm{p}=0.030)$ was found between 25 $(\mathrm{OH}) \mathrm{D}$ levels and TST conversion with OR of 1.00, OR = 0.58 (95\% CI 0.08-3.24) and OR $=0.11$ (95\% CI 0.000.87 ), adjusted for high exposure and sputum AFB-positive index cases. The mean of $25(\mathrm{OH}) \mathrm{D}$ was $19.0 \pm 2.9$ $\mathrm{ng} / \mathrm{ml}$ in cases versus $26.3 \pm 14.0 \mathrm{ng} / \mathrm{ml}$ in controls $(\mathrm{p}=$ 0.094).

\section{Discussion}

The results indicated that a high proportions of contacts of TB patients had low serum 25(OH)D levels, and suggested that sufficient $25(\mathrm{OH}) \mathrm{D}$ levels protect against TST conversion. In the cross-sectional study, no differences in $25(\mathrm{OH}) \mathrm{D}$ levels were found between negative and positive LTBI participants.
Some studies have found high prevalence of low serum VitD levels in various Spanish populations [36-38], but this is not general [39]. No Spanish studies of VitD in contacts of TB patients have been published. In the international research on VitD and TB, Gibney and co-authors [24] observed that higher VitD levels were associated with lower probability of LTBI and TB disease in immigrants from Sub-Saharan Africa in Melbourne, Australia. In Vietnam, Ho-Pham and co-authors [40], in a matched case-control study of TB patients and controls, found that low serum 25(OH)D levels $(<30 \mathrm{ng} / \mathrm{ml})$ was a risk of tuberculosis in men, but not in women. In Greenland [41], a case-control study of TB patients and controls reported that $25(\mathrm{OH}) \mathrm{D}$ levels of $<75 \mathrm{nmol} / \mathrm{l}$ or $>140 \mathrm{nmol} / \mathrm{l}$ were associated with high risk for active TB. In Pakistan, a cohort study of household contacts of pulmonary TB patients found that VitD deficiency was a risk factor for active TB (Relative risk $=5.195 \%$ CI 1.2-21.3) [42], and this is consistent with our case-control study. Coinciding with phase I of our study, a cross-sectional study [25] of Mexican immigrants in Canada found no difference in 25 $(\mathrm{OH}) \mathrm{D}$ levels between positive LTBI cases and controls. In a cohort study of Greek dialysis patients, the use of VitD supplements was not associated with incidence of TB [43]. These studies vary in terms of design, geographic location 
Table 2 Prevalence of latent tuberculosis infection (LTBI) in the study population following the cross-sectional study

\begin{tabular}{|c|c|c|c|c|}
\hline Variables & Cases & $\begin{array}{l}\text { Controls } \\
\mathrm{n}=50(\%)\end{array}$ & $\begin{array}{l}\text { OR } 95 \% \mathrm{Cl} \\
\mathrm{n}=152(\%)\end{array}$ & $P$ value \\
\hline Age (years) (Mean \pm SD) & $38.0 \pm 16.9$ & $34.8 \pm 14.3$ & $1.02(0.99-1.04)$ & 0.151 \\
\hline Male & $35(70)$ & $77(50.7)$ & $2.27(1.15-4.50)$ & 0.019 \\
\hline Foreign-born & $22(44)$ & $61(40.1)$ & $1.17(0.61-2.24)$ & 0.630 \\
\hline BCG vaccinated & $24(48)$ & $74(48.7)$ & $0.97(0.51-1.84)$ & 0.933 \\
\hline Use vitamin D supplements $^{1}$ & $6(13.6)$ & $27(18.0)$ & $0.72(0.28-1.87)$ & 0.500 \\
\hline Ever smoking ${ }^{2}$ & $20(46.5)$ & $54(38.3)$ & $1.40(0.70-2.79)$ & 0.337 \\
\hline $\mathrm{BMI}^{3}($ Mean $\pm \mathrm{SD})$ & $25.7 \pm 4.7$ & $25.6 \pm 6.3$ & $1.03(0.97-1.11)$ & 0.315 \\
\hline Sputum AFB-positive index cases & $43(86)$ & $112(73.7)$ & $2.19(0.91-5.27)$ & 0.079 \\
\hline \multicolumn{5}{|l|}{ Exposure to TB patient } \\
\hline High & $28(52)$ & $36(23.7)$ & $7.58(2.42-23.74)$ & 0.001 \\
\hline Medium & $18(40)$ & $77(50.6)$ & $2.28(0.72-7.02)$ & 0.160 \\
\hline Low & $4(8)$ & $39(25.7)$ & 1.00 & \\
\hline Trend & & & & 0.000 \\
\hline High exposure and sputum AFB-positive index cases & 23(46) & $17(11.2)$ & $6.76(3.19-14.33)$ & 0.000 \\
\hline Study period Apr-Sept & $32(64)$ & $98(64.5)$ & $0.98(0.50-1.91)$ & 0.952 \\
\hline $25(\mathrm{OH})$ Vitamin $\mathrm{D}_{3} \mathrm{ng} / \mathrm{ml}$ (Mean $\left.\pm \mathrm{SD}\right)$ & $22.9 \pm 11.0$ & $24.0 \pm 14.1$ & & $0.875^{4}$ \\
\hline $25(\mathrm{OH})$ Vitamin $\mathrm{D}_{3} \mathrm{ng} / \mathrm{ml}($ Mean $\pm \mathrm{SD})$ Oct-March period & $17.9 \pm 7.0$ & $18.2 \pm 8.0$ & & $0.800^{4}$ \\
\hline $25(\mathrm{OH})$ Vitamin $\mathrm{D}_{3} \mathrm{ng} / \mathrm{ml}($ Mean $\pm \mathrm{SD})$ Apr-Sept period & $25.7 \pm 11.9$ & $27.2 \pm 15.7$ & & $0.957^{4}$ \\
\hline $25(\mathrm{OH})$ Vitamin $\mathrm{D}_{3} \geq 30 \mathrm{ng} / \mathrm{ml}$ & $9(18)$ & $32(21.1)$ & $0.82(0.36-1.87)$ & 0.642 \\
\hline \multicolumn{5}{|l|}{$25(\mathrm{OH})$ Vitamin $\mathrm{D}_{3}$ levels } \\
\hline 0-19 ng/ml & $22(44)$ & $67(44.1)$ & 1.00 & \\
\hline $20-29 \mathrm{ng} / \mathrm{ml}$ & $19(38)$ & $53(34.9)$ & $1.09(0.54-2.22)$ & \\
\hline $30 \geq \mathrm{ng} / \mathrm{ml}$ & $9(18)$ & $32(21.1)$ & $0.86(0.35-2.07)$ & \\
\hline Trend & & & & 0.812 \\
\hline
\end{tabular}

Comparison of positive LTBI cases and controls. Odds ratios (OR) and 95\% confidence interval (CI).

(1) Information on 194 participants. (2) Information on184 participants. (3) Information on 174 participants. (4) Kruskal-Wallis test. SD = Standard deviation. BMI = Body mass index. AFB = Acid fast bacilli $\mathrm{TB}=$ tuberculosis.

and population, and some questions remain in relation to gender differences, the use of VitD supplements, and the effects of serum VitD levels.

The antimicrobial effects of VitD have motivated intense research [44]. In relation to $M$. tuberculosis, metabolites of VitD, calcitriol and the induced peptides, cathelicidin and defensina beta 4 , have an important effect in eliminating the bacilli, including enhancement of macrophage phagocytosis, activation of monocytes, cytokines modulation, limitation of intracellular growth

Table 3 Characteristic of participants with tuberculin skin test (TST) conversion

\begin{tabular}{|c|c|c|c|c|c|c|c|c|c|}
\hline $\begin{array}{l}\mathbf{N} \\
\circ\end{array}$ & Age & Gender & $\begin{array}{l}\text { Foreign- } \\
\text { born }\end{array}$ & $\begin{array}{l}\text { Sputum AFB-positive index } \\
\text { cases }\end{array}$ & $\begin{array}{l}\text { Exposure to TB } \\
\text { patient }\end{array}$ & $\begin{array}{l}\mathrm{BCG} \\
\text { vaccine }\end{array}$ & $\begin{array}{l}\text { Primary } \\
\text { prophylaxis }\end{array}$ & $\begin{array}{l}\text { TST } \\
1^{\mathrm{a}}\end{array}$ & $\begin{array}{l}\text { TST } \\
2^{a}\end{array}$ \\
\hline 1 & 6 & Female & No & Yes & High & No & Yes & 0 & 16 \\
\hline 2 & 21 & Female & Yes & Yes & High & No & No & 0 & 12 \\
\hline 3 & 22 & Male & Yes & Yes & Medium & Yes & No & 2 & 12 \\
\hline 4 & 27 & Male & No & Yes & High & No & No & 2 & 9 \\
\hline 5 & 34 & Male & Yes & Yes & High & Yes & No & 10 & 28 \\
\hline 6 & 37 & Male & No & Yes & High & $\mathrm{No}$ & No & 0 & 30 \\
\hline 7 & 38 & Male & $\mathrm{No}$ & Yes & Medium & No & No & 1 & 8 \\
\hline 8 & 42 & Female & Yes & Yes & High & Yes & No & 0 & 20 \\
\hline 9 & 46 & Male & No & Yes & Medium & Yes & No & 9 & $16^{1}$ \\
\hline 10 & 55 & Male & No & Yes & Medium & Yes & No & 9 & 19 \\
\hline 11 & 56 & Female & Yes & $\mathrm{No}^{2}$ & Medium & No & No & 4 & 13 \\
\hline 12 & 57 & Female & No & Yes & Medium & No & No & 0 & 7 \\
\hline
\end{tabular}

(1) Presence of vesicles. (2) Contact with culture positive pulmonary TB patient.

AFB = Acid Fast Bacilli; BCG = Bacilli Calmette-Guerin; TST $=$ Tuberculin Skin Test TB $=$ Tuberculosis 
Table 4 Incidence of tuberculin skin tests (TST) conversion following the case-control study

\begin{tabular}{|c|c|c|c|c|}
\hline Variables & $\begin{array}{l}\text { Cases } \\
\mathrm{N}=11(\%)\end{array}$ & $\begin{array}{l}\text { Controls } \\
\mathrm{N}=82(\%)\end{array}$ & OR $95 \% \mathrm{Cl}$ & $P$ value \\
\hline Age (years) (Mean \pm SD) & $39.6 \pm 13.1$ & $34.7 \pm 14.5$ & $1.02(0.98-1.07)$ & 0.299 \\
\hline Male & $8(72.7)$ & $41(50.0)$ & $2.07(0.66-10.72)$ & 0.168 \\
\hline Foreign-born & $5(45.5)$ & $26(31.7)$ & $1.79(0.50-6.42)$ & 0.363 \\
\hline BCG vaccinated & $5(45.5)$ & $40(48.8)$ & $0.88(0.25-3.10)$ & 0.886 \\
\hline Use vitamin D supplements & $3(27.3)$ & $20(24.7)^{1}$ & $1.14(0.28-4.73)$ & 0.853 \\
\hline Ever smoking & $6(54.5)$ & $30(38.5)^{2}$ & $1.96(0.55-6.98)$ & 0.299 \\
\hline BMI $(\text { Mean } \pm S D)^{3}$ & $25.4 \pm 4.6$ & $26.0 \pm 6.4$ & $0.98(0.88-1.10)$ & 0.749 \\
\hline Contact sputum AFB-positive index cases & $10(90.9)$ & $65(79.3)$ & $2.62(0.31-21.87)$ & 0.375 \\
\hline \multicolumn{5}{|l|}{ Exposure to TB patient } \\
\hline High & $5(45.5)$ & $14(17.1)$ & $9.16(1.14-\infty)$ & 0.035 \\
\hline Medium & $6(54.5)$ & $47(57.3)$ & $3.51(0.49-\infty)$ & 0.248 \\
\hline Low & $0(0.0)$ & $21(25.6)$ & 1.00 & \\
\hline Trend & & & & 0.014 \\
\hline High exposure and sputum AFB positive index cases & $5(45.5)$ & $6(7.3)$ & $10.56(2.48-44.95)$ & 0.001 \\
\hline Study period Apr-Sept & $6(54.5 \%)$ & $61(74.4)$ & $0.41(0.11-1.50)$ & 0.178 \\
\hline $25(\mathrm{OH})$ Vitamin $\mathrm{D}_{3}(\mathrm{ng} / \mathrm{ml})($ Mean $\pm \mathrm{SD})$ & $17.5 \pm 5.6$ & $25.9 \pm 13.7$ & & $0.041^{4}$ \\
\hline $25(\mathrm{OH})$ Vitamin $\mathrm{D}_{3} \mathrm{ng} / \mathrm{ml}$ (Mean $\pm \mathrm{SD}$ ) Oct-March period & $15.3 \pm 7.4$ & $20.0 \pm 9.3$ & & $0.242^{4}$ \\
\hline $25(\mathrm{OH})$ Vitamin $D_{3} \mathrm{ng} / \mathrm{ml}$ (Mean $\pm \mathrm{SD}$ ) Apr-Sept period & $19.4 \pm 2.9$ & $27.9 \pm 14.4$ & & $0.144^{4}$ \\
\hline $25(\mathrm{OH})$ Vitamin $\mathrm{D}_{3} \geq 30 \mathrm{ng} / \mathrm{ml}$ & $0(0)$ & $25(30.5)$ & $0.15(0.00-1.00)$ & $0.050^{5}$ \\
\hline \multicolumn{5}{|l|}{$25(\mathrm{OH})$ Vitamin $\mathrm{D}_{3}$ levels } \\
\hline 0-19 ng/ml & $7(63.6)$ & $29(35.4)$ & 1.00 & \\
\hline $20-29 \mathrm{ng} / \mathrm{ml}$ & $4(36.4)$ & $28(34.1)$ & $0.60(0.12-2.66)$ & 0.660 \\
\hline$\geq 30 \mathrm{ng} / \mathrm{ml}$ & $0(0.0)$ & $25(30.5)$ & $0.13(0.00-0.91)$ & 0.038 \\
\hline Trend & & & & 0.034 \\
\hline
\end{tabular}

Comparison of TST conversion cases and controls. Odds ratios (OR) and 95\% confidence interval (CI).

(1) Information on 81 controls. (2) Information on 78 controls. (3) Information on 10 cases and 75 controls.(4) Kruskal-Wallis test. (5) Fisher test $p=0.033$. SD = Standard Deviation. BCG = Bacilli Calmette-Guérin. BMI = Body Mass Index AFB = Acid Fast Bacilli. TB = Tuberculosis

of M. tuberculosis, and suppression of enzymes involved in pulmonary cavitation [45-48]. In addition, the vitamin $\mathrm{D}$ receptor gene polymorphism plays a key role in susceptibility to TB [49].

The strengths of our study include the following: its design is prospective, it studied the contacts of recent diagnosed TB patients with actual exposure to $M$. tuberculosis, seasonal sunlight variations occurred during the study, multivariate analysis was applied to control potential confusion factors and risk of exposure, and a valid technique was used to determine $25(\mathrm{OH}) \mathrm{D}$ levels [50].
The study has some limitations, however. The size of the study in relation to TST conversion is small. Some potential confusion factors were studied but unknown factors could have been present. The measure of VitD status estimated 25-hydroxyvitamin $\mathrm{D}_{3}, 90 \%$ of VitD circulating in blood, and not vitamin $\mathrm{D}_{2}$, and the technique has some discordant sensitivity at range limits when it is compared with radioimmunoassay [51]. There is no gold standard for the diagnosis of LTBI and the presence of live $M$. tuberculosis in LTBI or TST conversion patients is unknown [52]. The TST has low specificity with the

Table 5 Risk and protective factors for tuberculin skin test conversion by logistic regression following the case-control study

\begin{tabular}{|c|c|c|c|}
\hline Variables & OR & $95 \% \mathrm{Cl}$ & $P$ value \\
\hline \multicolumn{4}{|l|}{$25(\mathrm{OH})$ Vitamin $\mathrm{D}_{3}$ levels } \\
\hline 0-19 ng/ml & 1.00 & & \\
\hline $20-29 \mathrm{ng} / \mathrm{ml}$ & 0.49 & $(0.07-2.59)$ & 0.563 \\
\hline$\geq 30 \mathrm{ng} / \mathrm{ml}$ & 0.10 & $(0.00-0.76)$ & 0.024 \\
\hline Trend & & & 0.019 \\
\hline High exposure TB and sputum AFB positive index cases & 14.19 & $(2.15-120.64)$ & 0.004 \\
\hline
\end{tabular}

Odds ratios (OR) and $95 \%$ confidence interval $(\mathrm{Cl})$.

AFB $=$ Acid Fast Bacilli. TB $=$ Tuberculosis 
possibility of false-positive results [53]. Two sources of false-positive results are Non-tuberculous Mycobacteria (NTMB) and BCG vaccination. In Spain, the frequency of NTMB is considered low, but the proportion of BCGvaccinated people over the age of 40 is high, and interferon- $\gamma$ release assays (IGRAS) tests were not used [54]. A booster TST was performed to deal with this issue. In addition, the incidence of TST conversion was in the range of results from several other studies of TB contacts in Spain, 7.8\%-12.5\% [55,56]. In the cross-sectional study, the participants presented significant differences from the non-participants, which is a limitation. However, the selection bias could be reduced, considering that participation might not be associated with VitD status. In the case-control study, only the foreign-born proportion of non-participants was significantly different. In addition, the participation rate in the case-control study was higher than the rates published in other studies in Spain, range $21.1 \%-63.3 \%$ [55]. Finally, no polymorphism study of VitD was carried out.

TB patients frequently have lower VitD levels than the general population [57] and research is still studying the effect of VitD on the course of the TB disease. In a recent clinical trial [48], the administration of VitD decreased the time of sputum culture conversion in pulmonary $\mathrm{TB}$ patients, but the decrease was only significant in patients with the group $\mathrm{tt}$ genotype of the TaqI vitamin D receptor polymorphism. In contrast, in another clinical trial [58] the administration of VitD did not improve clinical symptoms of TB patients. Our study indicates that it could be useful to determine $25(\mathrm{OH}) \mathrm{D}$ status in contacts of TB patients as a risk factor for TST conversion. If low $25(\mathrm{OH})$ $\mathrm{D}$ levels are found, recommendations to take Vit D supplements are pertinent in order to achieve sufficient 25 $(\mathrm{OH}) \mathrm{D}$ levels. However, only a clinical trial could determine the therapeutic effects of VitD in contacts of TB patients [59].

\section{Conclusion}

The results of the study suggest that sufficient $25(\mathrm{OH}) \mathrm{D}$ levels protect against TST conversion and support the hypothesis that deficient VitD status is a TB risk factor.

\footnotetext{
List of abbreviations

ABF: acid-fast bacilli; BCG: bacilli Calmette Guerin; IGRAS: interferon- $\gamma$ release assays; IU: international units; LTBI: latent tuberculosis infection; PPD: purified protein derivative; SD: standard deviation; TB: tuberculosis; TST: tuberculin skin test; TU: tuberculin units; 25(OH)D: 25-hydroxyvitamin $\mathrm{D}_{3}$; VitD: vitamin D.
}

\section{Acknowledgements}

We thank the participants for their corporation in making this study possible.

\section{Author details}

${ }^{1}$ Epidemiology Division. Public Health Center Castellón, Spain. ${ }^{2}$ Laboratory of Biochemical. Hospital General. Castellón, Spain. ${ }^{3}$ Preventive Medicine.
Hospital La Plana. Vila-real, Spain. ${ }^{4}$ CIBER of Epidemiology and Public Health (CIBERESP), Barcelona, Spain. ${ }^{5}$ Preventive Medicine. Hospital Provincial. Castellón, Spain.

\section{Authors' contributions}

AAP, and MARG designed the study; MARG, RHG, CHC, JBB, LSA, ESS, NMF and JIM carried out data collection and follow-up participants; LSA, ESS, and NMF performed the tuberculin skin test; JVJC, DGF, JIM, MJSP and JAFV performed determinations of $25(\mathrm{OH}) \mathrm{D} ; \mathrm{AAP}, \mathrm{NMF}$, and ESS carried out the statistical analysis; AAP, AFV, RHG, VRB contributed to writing up the manuscript; JBB, JVJC, JAFV and RHG reviewed the manuscript. All authors read and approved the final manuscript.

\section{Competing interests}

The authors declare that they have no competing interests.

Received: 4 July 2011 Accepted: 15 December 2011

Published: 15 December 2011

\section{References}

1. Davies PD, Brown RC, Woodhead JS: Serum concentrations of vitamin D metabolites in untreated tuberculosis. Thorax 1985, 40:187-190.

2. Sita-Lumsden A, Lapthorn G, Swaminathan R, Milburn HJ: Reactivation of tuberculosis and vitamin $D$ deficiency: the contribution of diet and exposure to sunlight. Thorax 2007, 62:1003-1007.

3. Nnoaham K, Clarke A: Low serum vitamin D levels and tuberculosis: a systematic review and meta-analysis. Int J Epidemiol 2008, 37:113-119.

4. Chan TYK: Vitamin D deficiency and susceptibility to tuberculosis. Calcif Tissue Int 2000, 66:476-478.

5. Wejse C, Olesen R, Rabna P, Kaestel P, Gustafson P, Aaby P, Andersen PL, Glerup H, Sodemann M: Serum 25-hydroxyvitamin D in West Africa population of tuberculosis patients and unmatched healthy controls. Am J Clin Nutr 2007, 86:1376-1383.

6. Williams B, Williams AJ, Anderson ST: Vitamin D deficiency and insufficiency in children with tuberculosis. Pediatr Infect Dis J 2008, 27:941-942.

7. Pérez-Trallero E, Cilla G, García-Zmalloa A, Idígoras P: Vitamin D and tuberculosis incidence in Spain. Am J Respir Crit Care Med 2008, 177:798-799.

8. Douglas AS, Strachan DP, Maxwell JD: Seasonality of tuberculosis: the reverse of other respiratory diseases in the UK. Thorax 1996, 51:944-946.

9. Thorpe LE, Frieden TR, Laserson KF, Wells C, Khatri G: Seasonality of tuberculosis in India: is it real and what does it tell us? Lancet 2004, 364:1613-1614.

10. Luquero FJ, Sanchéz-Padilla E, Simón-Soria F, Eiros JM, Golub JE: Trend and seasonality of tuberculosis in Spain, 1994-2004. Int J Tuber Lung Dis 2008, 12:221-224.

11. Akhtar S, Mohammad H: Seasonality in pulmonary tuberculosis among migrant workers entering Kuwait. BMC Infect Dis 2008, 8:3, doi:10.1186/ 1471-2334-8-3.

12. Wilson ME, Fineberg HV, Colditz GA: Geographic latitude and efficacy of bacillus Calmette-Guérin vaccine. Clin Infect Dis 1995, 20:982-91.

13. Zodpey SP, Shrikhande SN: The geographic location (latitude) of studies evaluating protective effect of BCG vaccine and it's efficacy/ effectiveness against tuberculosis. Indian J Public Health 2007, 51:205-210.

14. Martineau AR, Wilkinson RJ, Wilkinson KA, Newton SM, Kampmann B, Hall BN, Packe GE, Davidson RN, Eldridge SM, Maunsell ZJ, Rainbow SJ, Berry $J$ L, Griffiths $C J$ : A single dose of vitamin D enhances immunity to mycobacteria. Am J Respir Crit Care Med 2007, 176:208-213.

15. Gao L, Tao Y, Zhang L, Jin Q: Vitamin D receptor genetic polymorphisms and tuberculosis: updated systematic review and meta-analysis. Int $J$ Tuberc Lung Dis 2010, 14:15-23.

16. Bruce D, Ooi JH, Yu S, Cantorna MT: Vitamin D and host resistance to infection? Putting the cart in front of the horse. Exp Biol Med 2010, 235:921-927

17. Albert PJ, Proal AD, Marshall TG: Vitamin D: The alternative hypothesis. Autoimmun Rev 2009, 8:639-644.

18. Janmeja AK, Muhapatra PR: Seasonality of tuberculosis. Int J Tuberc Lung Dis 2005, 9:704-705.

19. Ríos M, García JM, Sánchez JA, Pérez D: A statistical analysis of the seasonality in pulmonary tuberculosis. Eur J Epidemiol 2000, 16:483-488. 
20. Atun RA, Samyshkin YA, Drobniewski F, Kuznetsov SI, Fedorin IM, Coker RJ: Seasonal variation and hospital utilization for tuberculosis in Russia: hospitals as social care institutions. Eur J Public Health 2005, 15:350-354.

21. Naranbat N, Nymadawa P, Schopfer K, Reider HL: Seasonality of tuberculosis in an Eastern-Asian country with an extreme continental climate. Eur Respir J 2009, 34:921-925.

22. Ustianowski A, Shaffer R, Collin S, Wilkinson RJ, Davidson RN: Prevalence and associations of vitamin $\mathrm{D}$ deficiency in foreign-born persons with tuberculosis in London. J Infect 2005, 50:432-437.

23. Bravis $\mathrm{V}, \mathrm{Al}$-Hadithy $\mathrm{H}$, Mak V: Prevalence of vitamin D deficiency in a London population diagnosed with active tuberculosis., London: Society for Endocrinology BES meeting 7-10 April 2008.

24. Gibney KB, MacGregor L, Leder K, Torresi J, Marshall C, Ebeling PR, Beverley $A B$ : Vitamin $D$ deficiency is associated with tuberculosis and latent tuberculosis infection in immigrants from Sub-Saharan Africa. Clin Infect Dis 2008, 46:443-446.

25. Merion T: Vitamin D status and latent tuberculosis infection: a preliminary study in a group of healthy Mexican agricultural workers. Faculty of Applied Health Sciences, Brock University, St Catharines, Ontario 2009., web visit November 20, 2010 http://dr.library.brocku.ca.

26. Grupo de Trabajo sobre la Tuberculosis: Consenso nacional para el control de la tuberculosis en España. Med Clin (Barc) 1992, 98:24-31.

27. Roth HJ, Schmidt-Gayk H, Weber H, Niederau C: Accuracy and clinical implications of seven 25-hydroxyvitamin D methods compared with liquid chromatography-tandem mass spectrometry as a reference. Ann Clin Biochem 2008, 45:153-159.

28. Leino A, Turpeinen $U$, Koskinen P: Automated measurement of $25-\mathrm{OH}$ vitamin $D_{3}$ on the Roche Modular E170 analyzer. Clin Chem 2008, 54:2059-2062.

29. Holick MF: Vitamin D deficiency. N Engl J Med 2007, 357:266-281.

30. Martínez- Sangrador M: Influencia de la exposición solar y la dieta en el estatus nutricional de vitamina $D$ en mujeres adolescentes y de edad avanzada: Estudio Optiford-Unión Europea. Tesis Doctoral. Universidad Complutense. Madrid 2006.

31. Comisión Técnica de Tuberculosis: Programa de prevención y control de tuberculosis. Valencia: Conselleria de Sanitat i Consum. Generalitat Valenciana 1993

32. Grupo de trabajo de la Tuberculosis de la Sociedad Española de Infectologia Pediatrica: Interpretación de la prueba de la tuberculina en niños. An Pediatr (Barc) 2003, 59:582-585.

33. Grupo de Estudio de Contactos de la UITB: Documento de consenso sobre el estudio de contactos en los pacientes tuberculosos. Med Clin (Barc) 1999, 112:151-6.

34. StataCopr. Stata Statistical Software: Release 9. College Station, TX: StataCorp; 2005.

35. Mehta C, Patel N: LogXact: user manual. Cambrige, MA: CYTEL; 1993.

36. Mata-Granados JM, Luque de Castro MD, Quesada-Gomez JM: Inappropriate serum levels of retinol, alpha-tocopherol, 25 hydroxyvitamin D3 and 24,25 dihydroxyvitamin D3 levels in healthy Spanish adults: simultaneous assessment by HPLC. Clin Biochem 2008, 41:676-680.

37. González M, Romagosa A, Zabaleta E, Gudiña N, Pozo C, Moreno R, Vilamala M: Deficiencia de vitamina $D$ en mujeres en edad fértil. Aten Primaria 2008, 40:393-399.

38. Calatayud M, Jódar E, Sánchez R, Guadalix S, Hawkins F: Prevalencia de concentraciones deficientes e insuficientes de vitamina $D$ en una población joven y sana. Endocrinol Nutr 2009, 56:164-169.

39. Bernal M, Cortés G, Giner A, Orden I, Horno M, Benedicto I: ¿Ha mejorado la dotación de vitamina D3 en España? Actuales niveles en una muestra de población. Rev Esp Geriat Geront 2010, 45:15-18.

40. Ho-Pham L, Nguyen ND, Nguyen TT, Nguyen DH, Dung H, Bui PK, Nguyen VN, Nguyen TV: Association between vitamin D insufficiency and tuberculosis in a Vietnamese population. BMC Infect Dis 2010, 10:306, doi 10.1186/1471-2334-10-306.

41. Nielsen NO, Skifte T, Andersson M, Wohlfahrt J, Soborg B, Koch A Melbey M, Ladefoged K: Both high and low serum vitamin D concentrations are associated with tuberculosis: a case-control study in Greenland. Br J Nutr 2010, 104:1487-1491.

42. Talat N, Perry S, Parsonnet J, Dawood G, Hussain R: Vitamin D deficiency and tuberculosis progression. Emerg Infect Dis 2010, 15:853-855.
43. Christopoulos Al, Diamantopoulos AA, Dimopoulos PA, Goumenos DS, Barbalias GA: Risk factors for tuberculosis in dialysis patients: a prospective multi-center clinical trial. BMC Nephrol 2009, 10:36, doi: 10.1186/1471-2369-10-36.

44. Gombart AF: The vitamin D-antimicrobial peptide pathway and its role in protection against infection. Future Microbiol 2009, 4:1151-1165.

45. Chesney RW: Vitamin D and The Magic Mountain: the anti-infectious role of the vitamin. J Pediatr 2010, 156:698-703.

46. Hewison M: Vitamin D and the immune system: new perspectives on an old theme. Endocrinal Meta Clin North Am 2010, 39:365-379, doi 10.1016/ jecl 2010.02.010.

47. Liu PL, Schenk M, Walker VP, Dempsey PW, Kanchanapoomi M, Wheelwright M, Vazirnia A, Zhang X, Steinmeyer A, Zügel U, Hollis BW, Cheng G, Modlin RL: Convergence of IL-1 $\beta$ and VDR activation pathways in humans TLR 2/1 induced antimicrobial reponses. PloS One 2009, 4: e5810.

48. Martineau AR, Timms PM, Bothamley GH, Hanifa Y, Islam K, Claxton AP, Packe GE, Moore-Guillon JC, Darmalingam M, Davidson RN, Milburn HJ, Baker LV, Barker RD, Woodward NJ, Venton TR, Barnes KE, Mullet CJ, Coussens AK, Rutterford CM, Mein CA, Davies GR, Wilkinson RJ, Nikolayevskyy V, Drobniewski FA, Eldridge SM, Griffiths CJ: High-dose vitamin D3 during intensive-phase antimicrobial treatment of pulmonary tuberculosis: a double-blind randomised controlled trial. Lancet 2011, 377:242-250.

49. Wilkinson RJ, Llewelyn M, Tossi Z, Patel P, Pasvol G, Lalvani A, Wright D, Latif $M$, Davidson RN: Influence of vitamin D deficiency and vitamin D receptor polymorphisms on tuberculosis among Gujarati Asians in west London: a case-control study. Lancet 2000, 355:618-621.

50. Wallace AM, Gibson S, de la Hunty A, Lamberg-Allardt C, Ashwell M: Measurement of 25-hydroxyvitamin $D$ in the clinical laboratory: Current procedures, performance characteristics and limitations. Steroids 2010, 75:477-488.

51. Wagner D, Hanwell HEC, Vieth R: An evaluation of automated methods for measurement of serum 25-hydroyvitamin D. Clin Biochem 2009, 42:1549-1556.

52. Mack U, Migliori GB, Sester M, Rieder HL, Ehlers D, Goletti D, Bossink A, Magdorf K, Hölscher C, Kampmann B, Arend SM, Detjen A, Bothamley G, Zellweger JP, Milburn H, Diel R, Ravn P, Cobelenes F, Cardona PJ, Kan B, Solovic I, Duarte R, Cirillo DM, Lange C, for the TBNET: LTBI: latent tuberculosis infection or lasting immune response to $M$. tuberculosis? A TBNET consensus statement. Eur Respir J 2009, 33:956-973.

53. Mancuso JD, Toblers SK, Keep LW: Pseudoepidemics of tuberculin skin test conversions in the U.S. Army after recent deployments. Am J Respir Crit Care Med 2008, 177:1285-1289.

54. Schluger NW, Burzynski J: Recent advances in testing for latent TB. Chest 2010, 138:1456-1463.

55. Goris-Periera A, Fernández-Villar A, Chouciño-Garrico N, Otero-Baamonde M, Vázquez-Gallardó R: Factores predictivos de la aparición de nuevos casos de infección tuberculosa y viraje tuberculinico en un estudio de contactos. Enferm Clin 2008, 18:183-189.

56. Alsedà M, Godoy P: Estudio de contactos de enfermos tuberculosos en un área semi-urbana. Enferm Infecc Microbiol Clin 2003, 21:281-286.

57. Yamshchikov AV, Kurbatova E, Kumari M, Blumberg HM, Ziegler TR, Ray SM, Tangpricha V: Vitamin D status and antimicrobial peptide cathelicidin (LL-37) concentrations in patients with active pulmonary tuberculosis. Am J Clin Nutr 2010, 92:603-611.

58. Wejse C, Gomes VF, Rabna P, Gustafson P, Aaby P, Lisse IM, Andersen PI, Glerup $H$, Sodemann M: Vitamin D as supplementary treatment for tuberculosis: a double-blind, randomized, placebo-controlled trial. Am 」 Respir Crit Care Med 2009, 179:843-50.

59. Vieth $R$ : Vitamin $D$ nutrient to treat TB begs the prevention question. Lancet 2011, 377:189-190.

\section{Pre-publication history}

The pre-publication history for this paper can be accessed here: http://www.biomedcentral.com/1471-2334/11/349/prepub

doi:10.1186/1471-2334-11-349

Cite this article as: Arnedo-Pena et al.: Latent tuberculosis infection, tuberculin skin test and vitamin D status in contacts of tuberculosis patients: a cross-sectional and case-control study. BMC Infectious Diseases 2011 11:349. 